ORIGINAL ARTICLE

\title{
Evidence of an association between genetic variation of the coactivator PGC-1 $\beta$ and obesity
}

\author{
G Andersen, L Wegner, K Yanagisawa, C S Rose, J Lin, C Glümer, T Drivsholm, K Borch-Johnsen, \\ $T$ Jørgensen, T Hansen, B M Spiegelman, O Pedersen
}

J Med Genet 2005;42:402-407. doi: 10.1136/jmg.2004.026278

See end of article for authors' affiliations

Correspondence to:

Dr G Andersen, Steno

Diabetes Center, Niels

Steensens Vej 2, NSH2.

16, DK-2820 Gentofte,

Copenhagen, Denmark;

gtta@steno.dk

Received 13 August 2004

Revised 15November 2004

Accepted

21 November 2004

\begin{abstract}
Background: Peroxisome proliferator activated receptor- $\gamma$ coactivator-1 $\beta$ (PGC-1 $\beta$ ) is a recently identified homologue of the tissue specific coactivator PGC- $1 \alpha$, a coactivator of transcription factors such as the peroxisome proliferators activated receptors and nuclear respiratory factors. PGC- $1 \alpha$ is involved in adipogenesis, mitochondrial biogenesis, fatty acid $\beta$ oxidation, and hepatic gluconeogenesis.

Methods: We studied variation in the coding region of human PPARGCIB in Danish whites and related these variations to the prevalence of obesity and type 2 diabetes in population based samples.

Results: Twenty nucleotide variants were identified. In a study of 525 glucose tolerant subjects, the Ala203Pro and Val279lle variants were in almost complete linkage disequilibrium $\left(R^{2}=0.958\right)$. In a casecontrol study of obesity involving a total of 7790 subjects, the 203Pro allele was significantly less frequent among obese participants $(p=0.004$; minor allele frequencies: normal weight subjects $8.1 \% 195 \%$ confidence interval: 7.5 to 8.8$)$, overweight subjects $7.6 \%$ (7.0 to 8.3 ), obese subjects $6.5 \%(5.6$ to 7.3$)$ ). In a case-control study involving 1433 patients with type 2 diabetes and 4935 glucose tolerant control subjects, none of the examined variants were associated with type 2 diabetes.

Conclusions: Variation of PGC-1 $\beta$ may contribute to the pathogenesis of obesity, with a widespread Ala203 allele being a risk factor for the development of this common disorder.
\end{abstract}

$P$ eroxisome proliferator activated receptor- $\gamma$ coactivator$1 \alpha($ PGC- $1 \alpha)$ is a tissue specific coactivator of the nuclear receptor peroxisome proliferators activated receptors (PPARs) and multiple other transcription factors involved in adipogenesis, adipocyte gene expression, adaptive thermogenesis, mitochondrial biogenesis, fatty acid $\beta$ oxidation, hepatic gluconeogenesis, insulin secretion, and muscle fibre type specific differentiation. ${ }^{1-8}$ Human PGC- $1 \alpha$ is abundantly expressed in skeletal muscle, liver, heart, and kidney, and in smaller amounts in white adipose tissue (WAT), pancreas, and brain. ${ }^{9}{ }^{10}$ Previously, we reported the finding of a widespread PGC-1 $\alpha$ Gly482Ser polymorphism associated with an increased risk of type 2 diabetes mellitus among Danish whites, ${ }^{11}$ and a number of studies suggest that PGC$1 \alpha$ variants associate with other key features of the metabolic syndrome such as obesity, ${ }^{12}{ }^{13}$ hypertension, ${ }^{14}$ insulin resistance, ${ }^{15}$ and impaired insulin secretion. ${ }^{13}$

A novel homologue of PGC- $1 \alpha$, termed PGC-1 $\beta$ or PERC, has been identified and cloned, ${ }^{16-18}$ and shows several important motifs conserved between human PGC- $1 \alpha$ and PGC-1 $\beta$ such as an $N$ terminal LXXLL box (L being leucine and $X$ being any amino acid) and the RNA recognition motif at the $\mathrm{C}$ terminus. ${ }^{16}$ Northern hybridisation analysis, real time quantitative PCR, and RNase protection assays indicate that the expression of PGC-1B mRNA is highly tissue selective, with highest levels in skeletal muscle, brown adipose tissue, heart, and brain and lower levels in liver, kidney, and WAT. ${ }^{16-19}$ In contrast to PGC- $1 \alpha$, physiological conditions such as cold exposure, physical exercise, or adrenergic stimulation do not alter PGC-1 $\beta$ expression. ${ }^{18}{ }^{19}$ Conversely, increased PGC-1 $\beta$ expression levels have been observed upon fasting in two studies, ${ }^{16}{ }^{20}$ but not in a third study. ${ }^{18}$ It appears that the expression levels of PGC- $1 \beta$ correspond to the mitochondrial content of various tissues, and overexpression of PGC-1 $\beta$ in myoblasts increases the number of mitochondria. ${ }^{18}$

Owing to differential splicing at the $5^{\prime}$ and $3^{\prime}$ ends, at least four isoforms of human PGC-1 $\beta$ exist. The PGC-1 $\beta$ a isoform encodes $33 \mathrm{C}$ terminal amino acids that are lacking in PGC$1 \beta \mathrm{b}$, while PGC- $1 \beta \mathrm{b}$ encodes $27 \mathrm{C}$ terminal amino acids not found in PGC-1 $\beta a{ }^{18}$ At the $\mathrm{N}$ terminal, the PGC-1 $\beta 1$ transcript is 21 amino acids longer than PGC- $1 \beta 2$, and altogether they differ by 26 amino acids. Consequently, the four predicted PGC-1 $\beta$ proteins are 1023, 1017, 1002, and 996 amino acids in size, for isoforms $1 a, 1 b, 2 a$, and $2 b$, respectively. In addition, it has been reported ${ }^{16}$ that an additional PGC-1 $\beta$ isoform exists, which has been termed PERC-s (short isoform) and lacks 39 amino acids (residues 156-194) corresponding to exon 4, which contains a LXXLL motif (nuclear receptor box) believed to be essential in the interaction of the coactivator with the ligand binding domain of transcription factors. This short PGC-1 $\beta$ isoform possesses reduced ability in vitro to coactivate oestrogen receptor $\alpha$ in human and monkey cell lines. ${ }^{16}$ All isoforms of PGC- $1 \beta$ have the same reading frame. PGC-1 $\beta 1$, the most abundant isoform in skeletal muscle, heart, and brain, coactivates the nuclear receptors PPAR $\alpha$ and PPAR $\gamma .{ }^{17}{ }^{18}$ This fact and the observed correlation between PGC-1 $\beta$ mRNA expression and mitochondrial content has led to the hypothesis that PGC-1 $\beta$ might be involved in the maintenance of fatty acid oxidation and mitochondrial biogenesis. ${ }^{18}$

Although assessed in a limited number of participants, gene expression studies have demonstrated that PGC-1 $\beta$ is downregulated in skeletal muscle from patients with type 2 diabetes and from non-diabetic relatives of such patients. ${ }^{21}$ Moreover, the human PPARGCIB gene encoding PGC-1 $\beta$ is

Abbreviations: $B M I$, body mass index; LD, linkage disequilibrium; MAF, minor allele frequency; MALDI-TOF, matrix assisted laser desorption/ionisation time of flight; NGT, normal glucose tolerant; OGT, oral glucose tolerance test; $\mathrm{OHA}$, oral hypoglycaemic agent; PERC, PGC-1 related estrogen receptor coactivator; PGC, peroxisome proliferator activated receptor- $\gamma$ coactivator; PPAR, peroxisome proliferators activated receptor; SNP, single nucleotide polymorphism; SSCP, single strand conformational polymorphism; WAT, white adipose tissue; WHO, World Health Organization 
localised to chromosome 5q33.1 (flanked by markers D5S812 and D5S2015), a region that shows linkage to type 2 diabetes in obese subjects. ${ }^{22} 23$

We therefore consider PPARGCIB to be a biological and positional candidate gene for obesity and obesity related type 2 diabetes, owing to its tissue expression, its homology with PPARGClA, its chromosomal localisation with linkage to obesity related diabetes, its function as a key regulator of a series of transcription factors of the nuclear receptor superfamily involved in the control of energy metabolism, and its gene expression profile in patients with and in subjects prone to type 2 diabetes. The objectives of the present study were to identify novel variation in the coding region of PPARGCIB, and to relate identified variants to obesity and type 2 diabetes. We report the results of a mutation analysis of the four isoforms of PGC-1 $\beta$, the identification of 20 single nucleotide polymorphisms (SNPs), estimates of linkage disequilibrium (LD) between the variants, and their relationships with obesity and type 2 diabetes in relatively large study samples.

\section{METHODS}

\section{Mutation analysis and genotyping}

The coding region ( 14 exons) of PGC- $1 \beta$ isoforms $1 \mathrm{a}, 1 \mathrm{~b}, 2 \mathrm{a}$, and $2 \mathrm{~b}$ including intron-exon boundaries was divided into 23 segments (sized 177-332 nucleotides) for combined single strand conformational polymorphism (SSCP) and heteroduplex analysis performed as described previously. ${ }^{24}$ PCR amplification was carried out as reported previously. ${ }^{11}$ Primer sequences, $\mathrm{MgCl}_{2}$ concentrations, and annealing temperatures are available on request. Aberrantly migrating samples were bi-directionally sequenced using fluorescent chemistry (MWG-Biotech AG, Ebersberg, Germany).

In the initial study of 525 glucose tolerant subjects, the variants were genotyped using PCR restriction fragment length polymorphism (RFLP) analysis (table 1).

All restriction enzyme digests were separated in $4 \%$ agarose gels and visualised by ethidium bromide staining. In all other participants genotyping of the PGC-1 $\beta$ variants was performed using a chip based matrix assisted laser desorption/ ionisation time of flight (MALDI-TOF) mass spectrometry (DNA MassARRAY) of PCR generated primer extension products as described ${ }^{25}$. This method had a genotyping efficiency $>96 \%$. A total of 1242 DNA samples (corresponding to approximately $15 \%$ of the total number) were genotyped with both RFLP and MALDI-TOF, and no discrepancies in the genotype data were observed.

\section{Biochemical assays}

Blood samples were drawn after a 12 hour overnight fast. An oral glucose tolerance test (OGTT) was performed in all nondiabetic subjects. The $\mathrm{HbA}_{\mathrm{lc}}$, plasma glucose, and serum insulin concentrations were measured as described. ${ }^{26}$

\section{Patients}

For mutation detection, we examined DNA from 61 overweight or obese patients with type 2 diabetes (36 men, 25 women) recruited from the outpatient clinic at Steno Diabetes Center. The mean (SD) age of the patients was 62 (11) years, age at diagnosis was 54 (10) years, body mass index (BMI) 29.9 (1.8) kg/m², and $\mathrm{HbA}_{1 \mathrm{C}} 8.1$ (1.7)\%. More than $70 \%$ of the patients fulfilled the World Health Organization (WHO) criteria for the metabolic syndrome. The patients were treated with diet alone $(24 \%)$, with oral hypoglycaemic agents (OHA) (66\%), or with insulin alone or in combination with OHA $(10 \%)$.

Identified mutations were genotyped in an initial study of 525 (246 men, 279 women) unrelated glucose tolerant subjects sampled at random during 1994-1997 at Steno Diabetes Center and Research Centre for Prevention and Health $^{27}$ for estimation of LD. Mean (SD) age was 57 (10) years and BMI $25.8(3.7) \mathrm{kg} / \mathrm{m}^{2}$.

The case-control study of obesity was performed in 7790 subjects (3929 men, 3861 women) recruited from Steno Diabetes Center and Research Centre for Prevention and Health. ${ }^{28}$ The subjects were divided into three classes according to their BMI: normal weight $(\mathrm{n}=3129)$, with BMI $<25.0 \mathrm{~kg} / \mathrm{m}^{2}$; overweight $(\mathrm{n}=3085)$, with BMI in the range 25.0 to $29.9 \mathrm{~kg} / \mathrm{m}^{2}$; and obese subjects $(\mathrm{n}=1576)$, with $\mathrm{BMI} \geqslant 30.0 \mathrm{~kg} / \mathrm{m}^{2}$.

The case-control study of type 2 diabetes was performed in 1433 unrelated patients with type 2 diabetes and 4935 glucose tolerant control subjects recruited from the same sample from Steno Diabetes Center and Research Center for Prevention and Health. ${ }^{28}$ Diabetes was diagnosed according to 1999 WHO criteria. In the group of patients with type 2 diabetes (867 men, 566 women) the age was 57 (11) years, age at clinical diagnosis 52 (11) years, BMI 29.6 (5.3) kg/m², and $\mathrm{HbA}_{1 \mathrm{C}} 7.8(1.7) \%$. In the group of glucose tolerant control subjects (2295 men, 2640 women) the age was 46 (9) years and BMI $25.5(4.1) \mathrm{kg} / \mathrm{m}^{2}$. All control subjects underwent a standard $75 \mathrm{~g}$ oral glucose tolerance test and only subjects who were normal glucose tolerant (NGT) were included as control subjects in the study.

All participants were Danish whites by self report and recruited from the same area of Copenhagen. Informed written consent was obtained from all subjects before participation. The study was approved by the ethics committee of Copenhagen and performed in accordance with the principles of the Helsinki Declaration II.

\section{Statistical analysis}

Fisher's exact test was applied to examine differences in allele frequencies between cases and control subjects and logistic regression was applied to examine differences in genotype distributions with adjustment for sex, age, and BMI (where appropriate). The dichotomous outcome variable was either type 2 diabetes versus normal glucose tolerance or

Table 1 Gene variants, primers and restriction enzymes

\begin{tabular}{|c|c|c|}
\hline Variant & Primers $5^{\prime}-3^{\prime}$ & Enzyme \\
\hline Ala203Pro & $\begin{array}{l}\text { GTGGGGCTTTGTCAGTGAAT } \\
\text { GGACTCCTGGAGGCATGGTG }\end{array}$ & NlalV \\
\hline Arg265Gln & $\begin{array}{l}\text { GGGCCAGCCAGTGACCATGC } \\
\text { CAGGCGTGGCCAGACGGTA }\end{array}$ & BsoBI \\
\hline Val2791le* & GCAGGGCAGACCCTGGTGC & Hpall \\
\hline Arg292Ser & $\begin{array}{l}\text { CAGGAAACAGCTAG̈TACCGCCGGGACCAGGGCCAGG } \\
\text { CCGAGCCCCAGCCAGCT } \\
\text { CAGGCGTGGCAGACGGTA }\end{array}$ & Alul \\
\hline
\end{tabular}


obesity versus normal weight. A general linear model was used for testing quantitative traits in relation to genotype. Genotype and sex were entered in the model as fixed factors, and age and BMI (where appropriate) as covariates. Values of serum insulin were logarithmically transformed before analysis. A p value $<0.05$ was considered significant. LD was estimated as $R^{2}$, where $R^{2}=1$ in the case of complete linkage and $\mathrm{R}^{2}=0$ in the case of no linkage (www.ekstroem. com). Odds ratios were calculated using a generalised linear model in RGui (version 1.7.0). Logistic regression and analyses on quantitative traits were performed using Statistical Package for Social Science software (version 12.0; SPSS, Chicago, IL, USA) .

\section{"In silico" data analysis}

The human PPARGCIB nucleotide sequences were retrieved from NCBI (www.ncbi.nlm.nih.gov) with accession numbers AY188947, AY188948, AY188949, and AY188950. The intronexon boundary structure was defined from NCBI (Evidence Viewer) and confirmed from Ensembl (www.ensembl.org). A search for additional SNPs was performed using LocusLink from NCBI (www.ncbi.nlm.nih.gov/LocusLink). Protein translations were performed using BCM Search Launcher (searchlauncher.bcm.tmc.edu/seq-util/seq-util.html), and confirmed with the proteins from accession numbers AY188947-AY188950. Protein and nucleotide sequence alignments were performed using ClustalW (version 1.82; www.ebi.ac.uk/clustalw/index.html). Accession numbers for studies of protein homology were AAF18573 (human PGC$1 \alpha$ ), AAO40022-AAO40025 (human PGC-1 $\beta$ la, PGC-1 $\beta 1 b$, PGC-1 $\beta 2 a$, and PGC-1 $\beta 2 b$ ), NP 573512 (murine Pgc-1 $\beta$ ), and NP_788264 (rat Perc). Primers for PCRs were designed using the software Primer3 (www.genome.wi.mit.edu/cgi-bin/ primer/primer3_www.cgi).

\section{RESULTS}

The entire coding (translated) regions of the four PGC-1 $\beta$ isoforms $1 \mathrm{a}, 1 \mathrm{~b}, 2 \mathrm{a}$, and $2 \mathrm{~b}$, including intron-exon boundaries, were examined for mutations in 61 overweight or obese patients with type 2 diabetes applying SSCP and heteroduplex analysis at two different experimental settings. We identified a total of 20 variants ( 15 of these were novel) (fig 1). An "in silico" SNP search revealed no additional validated PGC- $1 \beta$ variants in the genomic region that was examined in the present study. The four isoforms of PGC-1 $\beta$ have two different translation initiation sites in the same reading frame, thus giving rise to two different ways of numbering the codons. In the following, all PGC- $1 \beta$ variants are denoted according to the most abundant human isoform PGC-1 $\beta 1$ a, which also corresponds to the longest polypeptide. Variants unique for its respective isoforms were not located in the translated regions, and thus the codon details can be converted from one isoform to another as listed in table 2, which also provides details of the observed nucleotide substitutions.

To estimate the degree of LD the four missense variants were investigated in a group of 525 glucose tolerant subjects. The Ala203Pro and Val279Ile variants were equally frequent and in almost complete $\mathrm{LD}\left(\mathrm{R}^{2}=0.958\right)$. There was no evidence of LD between the remaining combinations of the missense variants $\left(\mathrm{R}^{2}\right.$ values between 0.001 and 0.005$)$; however, this may be due to the relatively low frequency of the variants (table 2 ). Applying $\mathrm{R}^{2}$ analysis of genotype data generated by the SSCP screening (61 patients with type 2 diabetes) we estimated that the IVS2-8C $\rightarrow$ T and IVS2-4C $\rightarrow$ T variants were in close but not complete $\mathrm{LD}$, whereas the Gly746Gly and Ala762Ala variants were in complete LD. In addition, the Ala203Pro and Val279Ile variants were not in LD with any of the other identified variants.
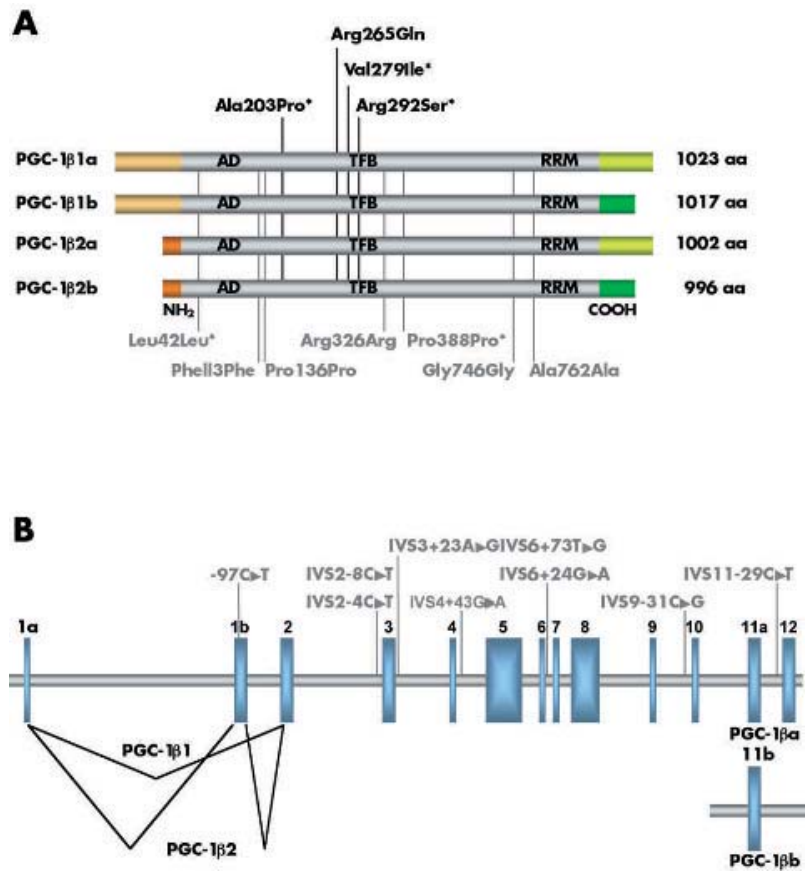

Figure 1 Schematic presentation of the PGC-1 $\beta$ protein and the genomic structure of PPARGCIB with indication of identified variants. (A) The approximate location of exon variants in the four PGC-1 $\beta$ proteins. The variants in black are amino acid substitutions; those in grey are silent. (B) The approximate location of intron variants. *Also found in existing SNP databases. AD, activation domain; TFB, transcription factor binding; RRM, RNA recognition motif.

The four missense variants (Ala203Pro, Arg265Gln, Val279Ile, and Arg292Ser) are all encoded by exon 5, and only the Arg292 allele is conserved between human PGC-1 $\beta$, murine Pgc- $1 \beta$, and rat Perc. Three of the four coding variants were genotyped in a group of white Danish subjects and examined in overlapping case-control studies of obesity $(n=7790)$ and type 2 diabetes $(\mathrm{n}=7545)$. Owing to the strong LD between the codon 203 and 279 variants, only one of these (the Ala203Pro variant) was genotyped in these study samples.

In the case-control study of obesity in 7790 Danish white subjects, we showed significant differences in allele frequencies and genotype distributions between normal weight and obese subjects for the Ala203Pro variant but not for the Arg265Gln or Arg292Ser variants (table 3). These differences were also present after exclusion of patients with known type 2 diabetes and after adjustment for glucose tolerance status among nondiabetic subjects (data not shown). Likewise, when stratifying the subjects according to sex, the Ala203Pro variant was associated with obesity for both men and women, although less convincingly for the women owing to the reduction in statistical power (data not shown). For the Ala203Pro variant, we investigated individual BMI levels in relation to genotype, and owing to the low number of Pro/Pro carriers $(n=42)$ we investigated a dominant model for the Pro allele. We observed a statistically significant difference in the two genotype groups $(p=0.01)$ and a relative decrease of 0.38 BMI units for Pro carriers compared with homozygote Ala/Ala carriers (data not shown). We also investigated the relationships of peripheral obesity (assessed by BMI adjusted for waist circumference) and central obesity (assessed by waist circumference adjusted for BMI) with the Ala203Pro genotype; however, no significant differences were observed (data not shown).

In the case-control study of type 2 diabetes, no differences in allele frequencies or genotype distributions were demonstrated between type 2 diabetic and glucose tolerant 
Table 2 Nucleotide substitutions, resulting amino acids, and number of carriers of the variants identified in PGC-1 $\beta$ among 61 overweight or obese white patients with type 2 diabetes

\begin{tabular}{|c|c|c|c|c|c|c|}
\hline $\begin{array}{l}\text { Nucleotide } \\
\text { substitution }\end{array}$ & $\begin{array}{l}\text { Nucleotide } \\
\text { location } \\
\text { (AY188947/ } \\
\text { AY188948) }\end{array}$ & $\begin{array}{l}\text { Amino acid } \\
\text { (PGC-1 } 1 \text { la } \\
\text { and }-1 b)\end{array}$ & $\begin{array}{l}\text { Nucleotide } \\
\text { location } \\
\text { (AY188949/ } \\
\text { AY188950) }\end{array}$ & $\begin{array}{l}\text { Amino acid } \\
\text { (PGC-1/2a } \\
\text { and }-2 b \text { ) }\end{array}$ & $\begin{array}{l}\text { Intronic/ } \\
\text { UTR } \\
\text { location }\end{array}$ & $\begin{array}{l}\text { No. of } \\
\text { patients }\end{array}$ \\
\hline $\mathrm{C} \rightarrow \mathrm{T}^{*}$ & & & & & $-97\left(5^{\prime}\right)$ & 23 \\
\hline $\mathrm{CTT} \rightarrow \mathrm{CTC}$ & 168 & Leu42Leu & 343 & Leu21 Leu & & 20 \\
\hline $\mathrm{C} \rightarrow \mathrm{T}$ & & & & & IVS2-8 & 3 \\
\hline $\mathrm{C} \rightarrow \mathrm{T}$ & & & & & IVS2-4 & 4 \\
\hline$\Pi \mathrm{TC} \rightarrow \Pi \mathrm{TT}$ & 381 & Phel13Phe & 556 & Phe92Phe & & 20 \\
\hline $\mathrm{CCC} \rightarrow \mathrm{CCG}$ & 450 & Prol36Pro & 625 & Prol 15Pro & & 1 \\
\hline$A \rightarrow G$ & & & & & IVS3+23 & 1 \\
\hline $\mathrm{G} \rightarrow \mathrm{A}$ & & & & & IVS4+43 & 1 \\
\hline $\mathrm{GCT} \rightarrow \mathrm{CCT}$ & 649 & Ala203Pro & 824 & Ala182Pro & & 8 \\
\hline $\mathrm{CGG} \rightarrow \mathrm{CAG}$ & 836 & Arg265Gln & 1011 & Arg244Gln & & 5 \\
\hline $\mathrm{G} \Pi \rightarrow \mathrm{ATT}$ & 877 & Val279lle & 1052 & Val258Ile & & 8 \\
\hline $\mathrm{CGC} \rightarrow \mathrm{AGC}$ & 916 & Arg292Ser & 1091 & Arg271Ser & & 3 \\
\hline $\mathrm{CGG} \rightarrow \mathrm{CGT}$ & 1020 & Arg326Arg & 1195 & Arg305Arg & & 2 \\
\hline $\mathrm{CCG} \rightarrow \mathrm{CCA}$ & 1206 & Pro388Pro & 1381 & Pro367Pro & & 21 \\
\hline $\mathrm{G} \rightarrow \mathrm{A}$ & & & & & IVS6+24 & 8 \\
\hline $\mathrm{T} \rightarrow \mathrm{G}$ & & & & & IVS6+73 & 23 \\
\hline $\mathrm{GGT} \rightarrow \mathrm{GGC}$ & 2280 & Gly746Gly & 2455 & Gly725Gly & & 3 \\
\hline $\mathrm{GCC} \rightarrow \mathrm{GCT}$ & 2328 & Ala762Ala & 2503 & Ala741Ala & & 3 \\
\hline$C \rightarrow G$ & & & & & IVS9-31 & 3 \\
\hline $\mathrm{C} \rightarrow \mathrm{T} \S$ & & & & & IVS11-29 & 2 \\
\hline
\end{tabular}

subjects for any of the three missense variants (table 4). Stratification according to degree of obesity did not change this observation (data not shown). For the Ala203Pro polymorphism, we investigated the relationships with fasting levels of plasma glucose and serum insulin, but no statistically significant differences between genotype groups were observed (data not shown). Likewise, there was no association of the Ala203Pro polymorphism with insulin resistance (estimated by homeostasis model assessment of insulin resistance), post-OGTT serum insulin, or plasma glucose, or fasting serum triglyceride or cholesterol concentrations (data not shown).

\section{DISCUSSION}

The identification of PGC- $1 \beta$ as a homologue of PGC- $1 \alpha^{16-18}$ makes human PPARGCIB a credible biological candidate gene for mutation analysis in relation to obesity and type 2 diabetes, as some previous observations ${ }^{11-1529}$ but not all, ${ }^{30} 31$ have correlated variation in human PGC- $1 \alpha$ with these common phenotypes. This idea is further strengthened by the evidence from genome scans of obesity associated type 2 diabetes showing independently replicated linkage with a chromosomal region encompassing the PPARGClB locus. ${ }^{22} 23$ Therefore, we tested the hypothesis that variation in the coding region of PPARGCIB contributes to the pathogenesis of obesity and type 2 diabetes.

The key finding of the present relatively large scale, population based study is the observation that the Ala203Pro variant of PGC-1 $\beta$, which was in almost complete LD with the Val279Ile variant, is less frequent among obese subjects compared with overweight and normal weight subjects (table 3). The odds ratio for Ala/Ala versus Pro/X

Table 3 Genotype distributions and allele frequencies of the PGC-1 $\beta$ variants in 7790 normal weight, overweight, and obese white Danish subjects

\begin{tabular}{|c|c|c|c|c|c|}
\hline & Normal $(n=3129)$ & $\begin{array}{l}\text { Overweight } \\
(\mathrm{n}=3085)\end{array}$ & Obese $(n=1576)$ & $\mathrm{P}_{\mathrm{AF}}$ & PGD \\
\hline \multicolumn{6}{|l|}{ Ala203Pro } \\
\hline Ala/Ala & $2636(84)$ & $2631(85)$ & $1380(88)$ & & \\
\hline Ala/Pro & $477(15)$ & $436(14)$ & 188 (12) & & \\
\hline Pro/Pro & $16(1)$ & $18(1)$ & $8(1)$ & & \\
\hline MAF & 8.1 (7.5 to 8.8$)$ & 7.6 (7.0 to 8.3$)$ & 6.5 (5.6 to 7.3$)$ & $0.004^{*}$ & $0.009^{*}$ \\
\hline \multicolumn{6}{|l|}{ Arg265Gln } \\
\hline Arg/Arg & $2767(90)$ & $2743(90)$ & 1391 (91) & & \\
\hline $\mathrm{Arg} / \mathrm{Gln}$ & $292(10)$ & $280(9)$ & 138 (9) & & \\
\hline$G \ln / G \ln$ & $8(0)$ & $11(0)$ & 8 (1) & & \\
\hline MAF & $5.0(4.5$ to 5.6$)$ & $5.0(4.4$ to 5.5$)$ & $5.0(4.2$ to 5.8$)$ & 1.0 & 0.3 \\
\hline \multicolumn{6}{|l|}{ Arg292Ser } \\
\hline Arg/Arg & $2890(94)$ & 2864 (94) & $1458(94)$ & & \\
\hline Arg/Ser & $185(6)$ & $176(6)$ & $92(6)$ & & \\
\hline Ser/Ser & $0(0)$ & $3(0)$ & $1(0)$ & & \\
\hline MAF & $3.0(2.6$ to 3.4$)$ & $3.0(2.6$ to 3.4$)$ & $3.0(2.4$ to 3.6$)$ & 0.9 & 0.5 \\
\hline
\end{tabular}

Normal: $B M I<25.0 \mathrm{~kg} / \mathrm{m}^{2}$; overweight: (BMI 25.0 to $\left.29.9 \mathrm{~kg} / \mathrm{m}^{2}\right)$; obese: $\left(B M I \geqslant 30.0 \mathrm{~kg} / \mathrm{m}^{2}\right)$. ${ }^{*}$ Significant $\mathrm{p}$ values. Data are number of subjects with each genotype (\% of each group) and percentage frequencies of the minor allele (MAF) $(95 \% \mathrm{Cl})$. The $p$ values compare genotype distribution $\left(\mathrm{p}_{\mathrm{GD}}\right)$ and allele frequencies $\left(\mathrm{p}_{\mathrm{AF}}\right)$ between normal weight and obese subjects and were calculated using Fisher's exact test $\left(p_{\mathrm{AF}}\right)$ and logistic regression with adjustment for age and sex ( $\mathrm{pGD}$ ) assuming a co-dominant model for the minor allele. 
Table 4 Genotype distributions and allele frequencies of the examined PGC-1 $\beta$ variants in 7545 subjects with normal glucose tolerance, impaired glucose tolerance/impaired fasting glucose, and type 2 diabetes

\begin{tabular}{|c|c|c|c|c|c|}
\hline & $\begin{array}{l}\text { Type } 2 \text { diabetic } \\
\text { patients }(n=1433)\end{array}$ & $\begin{array}{l}\text { Subjects with IFG } \\
+ \text { IGT ( }=1177)\end{array}$ & $\begin{array}{l}\text { Glucose tolerant } \\
\text { subjects }(n=4935)\end{array}$ & $p_{A F}$ & $P_{G D}$ \\
\hline \multicolumn{6}{|l|}{ Ala203Pro } \\
\hline Ala/Ala & $1240(87)$ & $1010(86)$ & $4191(85)$ & & \\
\hline Ala/Pro & $186(13)$ & $160(14)$ & 717 (15) & & \\
\hline Pro/Pro & $7(0)$ & $7(1)$ & $27(1)$ & & \\
\hline MAF & 7.0 (6.0 to 7.9$)$ & $7.4(6.3$ to 8.4$)$ & $7.8(7.3$ to 8.3$)$ & 0.2 & 0.5 \\
\hline \multicolumn{6}{|l|}{ Arg265Gln } \\
\hline Arg/Arg & $1261(91)$ & $1046(91)$ & $4378(90)$ & & \\
\hline Arg/Gln & 125 (9) & $106(9)$ & $462(10)$ & & \\
\hline Gln/Gln & $3(0)$ & $2(0)$ & $21(0)$ & & \\
\hline MAF & $4.7(3.9$ to 5.5$)$ & 4.8 (3.9 to 5.6$)$ & $5.2(4.7$ to 5.6$)$ & 0.4 & 0.2 \\
\hline \multicolumn{6}{|l|}{ Arg292Ser } \\
\hline Arg/Arg & $1310(93)$ & 1095 (94) & $4582(94)$ & & \\
\hline Arg/Ser & $92(7)$ & $68(6)$ & $276(6)$ & & \\
\hline Ser/Ser & $0(0)$ & $2(0)$ & $2(0)$ & & \\
\hline MAF & 3.3 (2.6 to 3.9$)$ & 3.1 (2.4 to 3.8$)$ & 2.9 (2.5 to 3.2$)$ & 0.3 & 0.9 \\
\hline \multicolumn{6}{|c|}{$\begin{array}{l}\text { Data are number of subjects with each genotype (\% of each group) and percentage frequencies of the minor allele } \\
\text { (MAF) }(95 \% \mathrm{CI}) \text {. The } \mathrm{p} \text { values compare genotype distribution }\left(\mathrm{p}_{\mathrm{GD}}\right) \text { and allele frequencies }\left(\mathrm{p}_{\mathrm{AF}}\right) \text { between patients } \\
\text { with type } 2 \text { diabetes and glucose tolerant subjects and were calculated using Fisher's exact test ( } p_{\mathrm{AF}} \text { ) and logistic } \\
\left.\text { regression with adjustment for age, sex, and BMI ( } p_{G D}\right) \text { assuming a co-dominant model for the minor allele. }\end{array}$} \\
\hline
\end{tabular}

was $1.3(95 \%$ confidence interval 1.1 to $1.6 ; p=0.002)$ for obese versus normal weight subjects. If this finding can be replicated in independent case-control studies, it may suggest that the Ala203Pro and Val279Ile variants of PGC$1 \beta$, or an as yet unknown genomic variation at this locus with which these amino acid polymorphisms are in $\mathrm{LD}$, are related to altered whole body energy homeostasis. In addition, our finding should be interpreted in the context of a recent report on transgenic mice overexpressing PGC-1 $\beta$, which provides further evidence for a role of PGC-1 $\beta$ in energy expenditure. ${ }^{19}$ PGC-1 $\beta$ overexpression resulted in mice that were hyperphagic but lean, showing increased $\beta$ oxidation of fatty acids and decreased circulating levels of the appetite regulating hormone leptin. In addition, the mice had decreased serum insulin levels when fed a high fat diet, and they were resistant to the development of obesity. ${ }^{19}$ Additionally, in studies of skeletal muscle cells both PGC- $1 \alpha$ and PGC-1 $\beta$ have been shown to increase proton leak. ${ }^{32}$

The finding of an association between the Ala203Pro and Val279Ile variants of PGC-1 $\beta$ and obesity and BMI is in accordance with the interpretation that the primary impact of these variants is to influence body weight regulation. Interestingly, in a study of offspring of patients with type 2 diabetes undergoing a hyperinsulinaemic euglycaemic clamp, magnetic resonance spectroscopy measurements showed a significant reduction in the mitochondrial phosphorylation rate compared with glucose tolerant control subjects. ${ }^{33}$ This observation may be related to altered activities of PGC- $1 \alpha$ and PGC- $1 \beta$ potently regulating the transcriptional activity of the nuclear respiratory factor- $1,{ }^{17}$ a key protein in the expression of mitochondrial genes. We therefore hypothesise that the common Ala203 allele per se, and/or the linked Val allele at codon 279 of PGC-1 $\beta$, are polymorphism that are associated with reduced function of the encoded proteins. Alternatively, these amino acid variants are in LD with nucleotide variation within the PPARGCIB locus, conferring an increased risk of obesity. Clearly, this hypothesis remains to be tested in future in vitro experiments to assess the potential functional impact of the Ala203Pro and/or Val279Ile variants on the encoded protein and in extended genetic analyses covering the relevant chromosomal region. Such analyses may include regulatory regions important for the expression levels of PGC$1 \beta$ and/or intronic or untranslated regions of interest, for example, those identified from homology analyses using genomic nucleotide sequences from other species. Thus, a characterisation of the minimal promoter(s) of PPARGCIB is needed.

In conclusion, from the present study, we report the identification of a total of 20 single nucleotide variants in the coding region of PPARGCIB. Among these were four amino acid substitutions, of which two (Ala203Pro and Val279Ile) were in almost complete LD. The Ala203Pro variant associates with a decreased risk of obesity-that is, the common allele (Ala) is considered to be the allele conferring increased risk of obesity. More extensive studies are needed to elucidate if the Ala203Pro and/or Val279Ile variants of PGC-1 $\beta$ are functional or are to be regarded as SNP markers in LD with as yet unidentified causative variants in the PPARGCIB locus. Relevant studies of quantitative traits to elucidate the physiological influences of these PGC-1 $\beta$ variants include a hyperinsulinaemic euglycaemic clamp in combination with infusion of tritiated glucose, indirect calorimetry, and magnetic resonance spectroscopy with measurements of basal and insulin stimulated hepatic gluconeogenesis, basal and insulin stimulated peripheral glucose disposal rate, lipid oxidation rate, and mitochondrial phosphorylation rate in muscle and adipose tissues.

\section{ACKNOWLEDGEMENTS}

The authors thank Dr B Thorsteinsson for recruiting some of the patients with type 2 diabetes. The study was supported by The Danish Medical Research Council, the Danish Diabetes Association, the Danish Heart Foundation, the Velux Foundation, EEC (BMH4-CT983084 and QLRT-CT-1999-00 546), the Japan Diabetes Foundation, and the Shiseikai Overseas Research Foundation.

\section{Authors' affiliations}

G Andersen, L Wegner, K Yanagisawa, C S Rose, C Glümer, K BorchJohnsen, T Hansen, O Pedersen, Steno Diabetes Center, Gentofte, Denmark

J Lin, B M Spiegelman, Dana-Farber Cancer Institute and the Department of Cell Biology, Harvard Medical School, Boston, USA C Glümer, T Drivsholm, K Borch-Johnsen, T Jørgensen, Research Centre for Prevention and Health, Copenhagen County, Glostrup University Hospital, Denmark

K Borch-Johnsen, O Pedersen, Faculty of Health Science, University of Aarhus, Denmark

Competing interests: none declared 


\section{REFERENCES}

1 Puigserver P, Wu Z, Park CW, Graves R, Wright M, Spiegelman BM. A coldinducible coactivator of nuclear receptors linked to adaptive thermogenesis. Cell 1998;92:829-39

2 Wu Z, Puigserver P, Andersson U, Zhang C, Adelmant G, Mootha V, Troy A, Cinti S, Lowell B, Scarpulla RC, Spiegelman BM. Mechanisms controlling mitochondrial biogenesis and respiration through the thermogenic coactivator PGC-1. Cell 1999;98:115-24.

3 Lehman JJ, Barger PM, Kovacs A, Saffitz JE, Medeiros DM, Kelly DP. Peroxisome proliferator-activated receptor $\gamma$ coactivator- 1 promotes cardiac mitochondrial biogenesis. J Clin Invest 2000;106:847-56.

4 Vega RB, Huss JM, Kelly DP. The coactivator PGC-1 cooperates with peroxisome proliferator-activated receptor $\alpha$ in transcriptional control of nuclear genes encoding mitochondrial fatty acid oxidation enzymes. Mol Cell Biol 2000;20:1868-76.

5 Herzig S, Long F, Jhala US, Hedrick S, Quinn R, Baver A, Rudolph D, Schutz G, Yoon C, Puigserver P, Spiegelman B, Montmint M. CREB regulates hepatic gluconeogenesis through the coactivator PGC-1. Nature 2001;413:179-83.

6 Michael LF, Wu Z, Cheatham RB, Puigserver P, Adelmant G, Lehman JJ, Kelly DP, Spiegelman BM. Restoration of insulin-sensitive glucose transporter (GLUT4) gene expression in muscle cells by the transcriptional coactivator PGC-1. Proc Natl Acad Sci USA 2001;98:3820-5.

7 Yoon JC, Puigserver P, Chen G, Donovan J, Wu Z, Rhee J, Adelmant G, Stafford J, Kahn CR, Granner DK, Newgard CB, Spiegelman BM. Control of hepatic gluconeogenesis through the transcriptional coactivator PGC-1. Nature 2001;413:131-8.

8 Lin J, Wu H, Tarr PT, Zhang C-Y, Wu Z, Boss O, Michael LF, Puigserver P, Isotani E, Olson EN, Lowell BB, Bassel-Duby R, Spiegelman BM. Transcriptional co-activator PGC- $1 \alpha$ drives the formation of slow-twitch muscle fibres. Nature 2002:418:797-801.

9 Esterbauer $\mathbf{H}$, Oberkofler H, Krempler F, Patsch W. Human peroxisome proliferator activated receptor gamma coactivator 1 (PPARGC1) gene: cDNA sequence, genomic organization, chromosomal localization, and tissue expression. Genomics 1999:62:98-102.

10 Larrouy D, Vidal H, Andreelli F, Laville M, Langin D. Cloning and mRNA tissue distribution of human PPAR $\gamma$ coactivator-1. Int $J$ Obes 1999;23:1327-32.

11 Ek J, Andersen G, Urhammer SA, Gæde PH, Drivsholm T, Borch-Johnsen K Hansen T, Pedersen O. Mutation analysis of peroxisome proliferator-activated receptor- $\gamma$ coactivator-1 (PGC-1) and relationships of identified amino acid polymorphisms to type II diabetes mellitus. Diabetologia $2001 ; 44: 2220-6$.

12 Esterbauer H, Oberkofler H, Linnemayr V, Iglseder B, Hedegger M, Wolfsgruber P, Paulweber B, Fastner G, Krempler F, Patsch W. Peroxisome proliferator-activated receptor- $\gamma$ coactivator- 1 gene locus. Associations with obesity indices in middle-aged women. Diabetes 2002;51:1281-6.

13 Muller YL, Bogardus C, Pedersen O, Baier L. A Gly482Ser missense mutation in the peroxisome proliferator-activated receptor $\gamma$ coactivator- 1 is associated with altered lipid oxidation and early insulin secretion in Pima Indians. Diabetes 2003;52:895-8.

14 Oberkofler H, Hölzl B, Esterbauer H, Xie M, Iglseder B, Krempler F, Paulweber B, Patsch W. Peroxisome proliferator-activated receptor- $\gamma$ coactivator-1 gene locus. Associations with hypertension in middle-aged men Hypertension 2003:41:368-72.

15 Hara K, Tobe K, Okada T, Kadowaki H, Akanuma Y, Ito C, Kimura S, Kadowaki T. A genetic variation in the PGC-1 gene could confer insulin resistance and susceptibility to type II diabetes. Diabetologia 2002;45:740-3.

16 Kressler D, Schreiber SN, Knutti D, Kralli A. The PGC-1-related protein PERC is a selective coactivator of estrogen receptor $\alpha$. J Biol Chem 2002;277:13918-25

17 Lin J, Puigserver P, Donovan J, Tarr P, Spiegelman BM. Peroxisome proliferator-activated receptor $\gamma$ coactivator $1 \beta$ (PGC-1 $\beta$ ), a novel PGC-1related transcription coactivator associated with host cell factor. J Biol Chem 2002;277:1645-8.

18 Meirhaeghe A, Crowley V, Lenaghan C, Lelliott C, Green K, Stewart A, Hart K, Schinner S, Sethi JK, Yeo G, Brand MD, Cortright RN, O'Rahilly S, Montague C, Vidal-Puig AJ. Characterization of the human, mouse and rat PGC1 $\beta$ (peroxisome-proliferator-activated receptor- $\gamma$ co-activator $1 \beta$ ) gene in vitro and in vivo. Biochem J 2003;373:155-65.

19 Kamei Y, Ohizumi H, Fujitani Y, Nemoto T, Tanaka T, Takahashi N, Kawada T, Miyoshi M, Ezaki O, Kakizuka A. PPAR $\gamma$ coactivator $1 \beta /$ /ERR ligand 1 is an ERR protein ligand, whose expression induces a high-energy expenditure and antagonizes obesity. Proc Natl Acad Sci USA 2003; 100: 12378-83.

20 Lin J, Tarr PT, Yang R, Rhee J, Puigserver P, Newgard CB, Spiegelman BM $P G C-1 \beta$ in the regulation of hepatic glucose and energy metabolism. J Biol Chem 2003;278:30843-8.

21 Patti ME, Butte AJ, Crunkhorn S, Cusi K, Berria R, Kashyap S, Miyazaki Y, Kohane I, Costello M, Saccone R, Landaker EJ, Goldfine AB, Mun E, DeFronzo R, Finlayson J, Kahn CR, Mandarino L. Coordinated reduction of genes of oxidative metabolism in humans with insulin resistance and diabetes: potential role of PGC1 and NRF1. Proc Natl Acad Sci USA 2003; 100:8466-71.

22 Vionnet N, Hani EH, Dupont S, Gallina S, Francke S, Dotte S, Matos FD, Durand E, Leprêtre F, Lecoeur C, Gallina P, Zekiri L, Dina C, Froguel P. Genomewide search for type 2 diabetes-susceptibility genes in French whites: evidence for a novel susceptibility locus for early-onset diabetes on chromosome 3q27-qter and independent replication of a type 2-diabetes locus on chromosome 1q21-q24. Am J Hum Genet 2000;67:1470-80.

23 Wiltshire S, Hattersley AT, Hitman GA, Walker M, Levy JC, Sampson M, O'Rahilly S, Frayling TM, Bell Jl, Lathrop GM, Bennett A, Dhillon R, Fletcher C, Groves CJ, Jones E, Prestwich P, Simecek N, Rao PVS, Wishart M, Foxon R, Howell S, Smedley D, Cardon LR, Menzel S, McCarthy MI. A genomewide scan for loci predisposing to type 2 diabetes in a U.K. population (the diabetes UK Warren 2 repository): analysis of 573 pedigrees provides independent replication of a susceptibility locus on chromosome 1q, Am J Hum Genet 2001:69:553-69.

24 Hansen T, Andersen CB, Echwald SM, Urhammer SA, Clausen JO Vestergaard H, Owens D, Hansen L, Pedersen O. Identification of a common amino acid polymorphism in the $\mathrm{p} 85 \alpha$ regulatory subunit of phosphatidylinositol 3-kinase. Diabetes 1997:46:494-501.

25 Buetow KH, Edmonson M, MacDonald R, Clifford R, Yip P, Kelley J, Little DP, Strausberg R, Koester H, Cantor CR, Braun A. High-throughput development and characterization of a genomewide collection of gene-based single nucleotide polymorphism markers by chip-based matrix-assisted laser desorption/ionization time-of-flight mass spectrometry. Proc Natl Acad Sci USA 2001;98:581-4

26 Hansen SK, Gjesing AP, Rasmussen SK, Glümer C, Urhammer SA, Andersen G, Rose CS, Drivsholm T, Torekov SK, Jensen DP, Ekstrøm CT, Borch-Johnsen K, Jørgensen T, McCarthy MI, Hansen T, Pedersen O. Largescale studies of the $\mathrm{Hphl}$ insulin gene variable-number-of-tandem-repeats polymorphism in relation to type 2 diabetes mellitus and insulin release. Diabetologia 2004;47:1079-87.

27 Drivsholm T, Ibsen H, Schroll M, Davidsen M, Borch-Johnsen K. Increasing prevalence of diabetes mellitus and impaired glucose tolerance among 60 year-old Danes. Diabet Med 2001;18:126-32.

28 Jørgensen T, Borch-Johnsen K, Thomsen TF, Ibsen H, Glümer C, Pisinger C. A randomized non-pharmacological intervention study for prevention of ischaemic heart disease: baseline results Inter99 (1). Eur J Cardiovasc Prevention Rehab 2003;10:377-86.

29 Oberkofler H, Linnemayr V, Weitgasser R, Klein K, Xie M, Iglseder B, Krempler F, Paulweber B, Patsch W. Complex haplotypes of the PGC-1 $\alpha$ gene are associated with carbohydrate metabolism and type 2 diabetes. Diabetes 2004;53:1385-93.

30 Lacquemant C, Chikri M, Boutin P, Samson C, Froguel P. No association between the G482S polymorphism of the proliferator-activated receptor coactivator-1 (PGC-1) gene and type II diabetes in French Caucasias. Diabetologia 2002;45:602-3.

31 Stumvoll M, Fritsche A, t'Hart LM, Machann J, Thamer C, Tschritter O, Van Haeften TW, Jacob S, Dekker JM, Maassen JA, Machicao F, Schick F, Heine RJ, Häring H. The Gly482Ser variant in the peroxisome proliferatoractivated receptor $\gamma$ coactivator- 1 is not associated with diabetes-related traits in non-diabetic German and Dutch populations. Exp Clin Endocrinol Diabetes 2004; 112:253-7.

32 St-Pierre J, Lin J, Krauss S, Tarr PT, Yang R, Newgard CB, Spiegelman BM. Bioenergetic analysis of peroxisome proliferator-activated receptor $\gamma$ coactivators $1 \alpha$ and $1 \beta$ (PGC- $1 \alpha$ and PGC-1 $\beta$ ) in muscle cells. J Biol Chem 2003;278:26597-603.

33 Petersen KF, Dufour S, Befroy D, Garcia R, Shulman GI. Impaired mitochondrial activity in the insulin-resistant offspring of patients with type 2 diabetes. N Engl J Med 2004;350:664-71. 